\title{
Identifikasi Pengunjung Pada Pantai Panrita Lopi, Kecamatan Muara Badak
}

\author{
Rini Koen Iswandari1 ${ }^{1,}$, Muhammad Fauzan Noor², Dini Zulfiani ${ }^{3}$ \\ 1 Politeknik Negeri Samarinda, Samarinda, Indonsia \\ 2 Politeknik Negeri Samarinda, Samarinda, Indonsia \\ ${ }^{3}$ Universitas Mulawarman Samarinda , Samarinda, Indonesia \\ ${ }^{1}$ rini2@polnes.ac.id; ${ }^{2}$ m.fauzan_noor@polnes.ac.id*; ${ }^{3}$ dini.zulfiani@fisip.unmul.ac.id \\ * Corresponding author
}

\begin{abstract}
Panrita Lopi Beach is one of the natural tourist destinations that needs to be surveyed by visitors in order to identify and determine strategies for developing tourist attractions and also marketing in Kutai Kartanegara Regency. This study aims to analyze the characteristics of tourists and travel patterns of tourists who visit and to determine the perception of the level of tourist satisfaction with infrastructure products, public facilities and tourism facilities in this tourist destination. The main variables used in segmenting consist of: Geographic Segmentation, Demographic Segmentation, Psychographic Segmentation, and Behavior-based Segmentation. This research is a type of survey research with a qualitative descriptive approach. Data collection is carried out from primary data sources and secondary data sources. The sample used in this study is a non-probability sampling technique by accidental sampling, namely a sampling technique based on chance, that is, anyone who coincidentally meets a researcher can be used as a sample, if it is deemed that the person who happened to be met is suitable as a data source. Data that has been collected from research results related to typology (characteristics, travel patterns) and visitor perceptions can be analyzed descriptively qualitatively. The analyzed data comes from surveys through questionnaires that have been given to visitors, including data on visitor profiles, visitor travel patterns, and visitor perceptions about this Panrita Lopi beach.
\end{abstract}

\section{ARTICLE HISTORY}

Submitted:05.10.2021

Revised:11.12.2021

Accepted:03.01.2022

Online first:05.01.2022

\section{KEYWORDS}

Profil of visitors, characteristics of tourists, Travel patterns, perceptions of tourists, market segmentation. 


\section{Pendahuluan}

Perkembangan sektor kepariwistaaan melalui kegiatan usaha pariwisata diharapkan memberikan efek berganda (multiplier effect) melalui aktivitas wisatawan di desnitasi pariwisata sehingga berdampak bagi percepatan pertumbuhan ekonomi secara nasional maupun regional/wilayah dan daerah.

Dampak ekonomiyang berasal dari aktivitas wisatawan sangat ditentukan oleh pengelolaan daya tarik wisata, aksesibilitas pariwisata, dan prasarana umum, fasilitas umum dan fasilitas pariwisata. Semakin baik pengelolaan daya tarik, fasilitas dan aksesibilitas maka semakin berpengaruh terhadap lamanya wisatawan berada di desnitasi wisata, dan juga pengeluaran wisatawan di destinasi wisata. Selain itu, strategi pemasaran yang efektif dan efisien juga menjadi hal yang sangat penting terutama untuk menentukan segmentasi pasar wisata.

Pengembangan prasarana umum, fasilitas umum dan fasilitas pariwisata bertujuan untuk dalam mendukung perintisan pengembangan destinasi wisata, mendukung pertumbuhan, meningkatkan kualitas dan daya saing destinasi wisata. Oleh karena itu perlu dukungan pemberian insentif untuk pengembangan Prasarana Umum, Fasilitas Umum, dan Fasilitas Pariwisata dalam mendukung perintisan Destinasi Pariwisata, meningkatkan fasilitasi pemerintah untuk pengembangan Prasarana Umum, Fasilitas Umum, dan Fasilitas Pariwisata atas inisiatif swasta, dan merintis dan mengembangkan Prasarana Umum, Fasilitas Umum, dan Fasilitas Pariwisata untuk mendukung kesiapan Destinasi Pariwisata dan meningkatkan daya saing Destinasi Pariwisata, dan mendorong untuk penyusunan regulasi perijinan untuk menjaga daya dukung lingkungan dan mendorong penegakan peraturan perundang-undangan.

Selain itu pemasaran juga menjadi salah satu aspek yang sangat penting, terdiri dari pengembangan pasar wisatawan, citra pariwisata, kemitraan dan promosi pariwisata. Pengembangan pasar wisatawan bertujuan untuk menentukan segmentasi pasar untuk mengoptimalkan pengembangan destinasi pariwisata dan dinamika pasar global.

Pemasaran pariwisata merupakan serangkaian proses untuk menciptakan, mengkomunikasikan, menyampaikan produk wisata dan mengelola relasi dengan 
wisatawan untuk mengembangkan kepariwi-sataan dan seluruh pemangku kepentingannya. (PP. Nomor 50 Tahun 2011).

Agar pelaksanaan pemasaran pariwisata dapat berjalan optimal, hal yang paling utama harus diperhatikan adalah pasar pariwisata perlu menyediakan semua kebutuhan pengunjung dan dengan cara apapun harus bisa menarik perhatian mereka.

Segmentasi Pasar wisatawan merupakan upaya yang dilakukan untuk membagi pasar wisata berdasarkan karakteristik wisatawan baik secara sosio-ekonomi, sosio-demografi, psikografi, maupun pola perjalanan wisatawan. (Cooper. et al, 1999).

Pantai Panrita Lopi adalah salah satu destinasi wisata alam yang ada di wilayah pesisir Kabupaten Kutai Kartanegara. Pantai ini lokasinya ada di sebuah pulau yang berjarak 62 kilometer dari pusat kota Samarinda dengan menempuh waktu sekitar 1 jam 50 menit, dari Samarinda ke Muara Badak. Tepatnya berlokasi di Pulau Pangempang, Desa Tanjung Limau, Kecamatan Muara Badak, Kabupaten Kutai Kartanegara.

Untuk mengetahui preferensi, tipologi atau kerakteristik wisatawan baik lokal maupun nasional yang berkunjung ke objek wisata di Kecamatan Muara Badak ini perlu dilakukan survey pengunjung dalam rangka identifikasi dan menentukan strategi pengembangan daya tarik wisata dan juga pemasaran di Kabupaten Kutai Kartanegara pada masa yangakan datang.

Penelitian ini bertujuan untuk menganalisa karakteristik wisatawan dan pola perjalanan wisatawan yang berkunjung ke pantai Panrita Lopi dan untuk mengetahui persepsi tingkat kepuasan wisatawan terhadap produk infrastruktur, fasilitas umum dan fasilitas pariwisata di destinasi wisata ini.

\section{Tinjauan Pustaka}

Segmentasi dalam pemasaran produk merupakan upaya untuk pemetaan konsumen yang memiliki karakteristik, daya beli, kebutuhan yang berbeda-beda di dalam situasi pasar tertentu, sehingga konsumen akan menargetkan pembelian produk sesuai strategi pemasaran yang dianutnya.

Menurut Kotler segmentasi pasar terdiri dari sekelompok pelanggan yang memiliki sekumpulan kebutuhan dan keinginan yang serupa, dengan demikian segmentasi pasar 
Edutourism Journal of Tourism Research $\quad$ p-ISSN: 2686-4746 e-ISSN: 2721-1371

pada dasarnya adalah kegiatan membagi-bagi pasar menjadi beberapa bagian sesuai dengan kebutuhan maupun karakteristik konsumen dengan tujuan produk yangakan dijual sesuai dengan kebutuhan dan keinginan konsumen.

Selanjutnya Kotler (2009) membagi segmentasi adalah membagi-bagi pasar dalam kelompok wisatawan secara tegas dan tiap kelompok itu dipilih atau ditetapkan sebagai target pasar yangakan dipengaruhi dengan menggunakan strategi bauran pemasaran.

Menurut Kasali (2000:119-120), segmen-tasi adalah proses mengkotak-kotakkan pasar yang heterogen ke dalam "potential customer" yang memiliki kesamaan kebutuhan dan/atau kesamaan karakter yang memiliki responsyang sama dalam membelanjakan uangnya.

Selanjutnya menurut Kotler bahwa variable utama yang digunakan dalam melakukan segmentasi terdiri atas:

1. Segmentasi Geografis, yaitu membagi pasar ke dalam unit-unit geografis, misalnya daerah/negara asal wisatawan yang berkunjung ke suatu daerah tujuan wisata. Unit-unit geografis ini dapat berupa negara, provinsi, kota, kabupaten, kota dan kecamatan.

2. Segmentasi Demografis, yaitu membagi pasar ke dalam kelompok-kelompok berdasar pada variabel demografis seperti umur, jenis kelamin, pendapatan, pekerjaan, pendidikan, agama dan kebangsaan.

3. Segmentasi Psikografis, yaitu membagi pasar ke dalam kelompok-kelompok berdasar kelas sosial, gaya hidup dankarakteristik pribadi/individu.

4. Segmentasi berdasar perilaku, yaitu membagi pasar ke dalam kelompok-kelompok berdasar pengetahuan mereka, sikap, penggunaan atau tanggapan terhadap suatu produk.

Sedangkan menurut Yoety (2002) menjelaskan bahwa pengertian segmentasi pasar tidak lain adalah suatu usaha untuk mengelompokkan konsumen dalam beberapa kelompok yang secara relatif orang-orang nya cukup homogen.

Dengan demikian, segmentasi pasar wisata merupakan upaya yang dilakukan untuk membagi-bagi atau memetakan pasar wisata berdasarkan karakteristik wisatawan dengan 
tujuan agar dalam melalukan pengembangan daya Tarik wisata, fasilitas wisata, maupun aksesibilitas sesuai dengan keinginan dan kebutuhan wisatawan.

Pola pergerakan wisatawan (tourist movement pattern) merupakan suatu pergerakan wisatawan dari satu atraksi ke atraksi lainnya atau dari suatu destinasi ke destinasi lainnya.

Wisatawan dengan tipe atau karakter tertentu akan mempengaruhi dalam memilih destinasi wisata. Menurut Cohen dalam Pitana (2010) membagi tipologi wisatawan menjadi empat yaitu:

1. Drifter yaitu wisatawan yang ingin mengunjungi daerah yang sama sekali belum diketahuinya dan bepergian dalam jumlah kecil.

2. Eksplorer yaitu wisatawan yang melakukan perjalanan dengan mengatur perjalanannya sendiri dengan memanfaatkan fasilitas dengan standar lokal dan tingkat interaksinya dengan masyarakat lokal juga tinggi.

3. Individual Mass Tourist, yaitu wisatawan yang meyerahkan pengaturan perjalanannya kepada agen perjalanan dan mengunjungi daerah tujuan wisata yang sudah terkenal.

4. Organized Mass Tourist, yaitu wisatawan yang hanya mau mengunjungi daerah tujuan wisata yang sudah dikenal dengan fasilitas dan perjalanannya selalu dipandu oleh pemandu wisata.

Persepsi merupakan kesan individu secara inderawi terhadap sesuatu yang pernah atau sedang dialami baik secara fisik (tangible) maupun non-fisik (intangible). Sedangkan persepsi wisatawan adalah kesan yang diwujudkan dalam bentuk interpretasi dan sikap terhadap daya tarik pariwisata, fasilitas pariwisata, fasilitas umum, informasi pariwisata serta pelayanan yang diberikan kepada wisatawan selama berada di obyek wisata tersebut. Setiap wisatawan yang melakukan perjalanan wisata memiliki persepsi yang berbeda terhadap obyek wisata yang didatangi, hal ini tergantung pada pengalaman berwisata, tingkat pendidikan, kondisi lingkungan, kondisi sosial-budaya negara asal wisatawan, serta pengaruh psikologis (Keliwar, 2015). 


\section{Metodologi Penelitian}

Penelitian ini dilaksanakan di Pantai Panrita Lopi, Kecamatan Muara Badak, Kabupaten Kutai Kartanegara di Propinsi Kalimantan Timur. Pemilihan lokasi ini sangatlah beralasan, karena dari total 13 pantai yang ada dengan perincian 9 di daerah teluk dan 4 di daerah Pangempang, destinasi inilah yang paling ramai dikunjungi wisatawan dan pantai ini juga telah melaksanakan event pesta pantai dengan menyelenggarkan beragam kegiatan atraksi menarik. Hal ini yang menjadi alasan penentuan lokasi penelitian tersebut sehingga diharapkan memperoleh data pengunjung yang akan di gunakan untuk mengkaji profil, pola perjalanan dan persepsi pengunjung untuk mengetahui segmentasi pasar wisatawan yang berkunjung di pantai ini.

Penelitian ini merupakan jenis penelitian survei dengan pendekatan deskriptif kualitatif. Pengumpulan data yang dilakukan bersumber dari sumber data primer dan sumber data sekunder. Sumber data primer diperoleh melalui observasi, dan kuesioner (daftar pertanyaan). Sedangkan sumber data sekunder diperoleh melalui data-data tambahan lainnya dari dinas pariwisata, serta bahan kajian kepustakaan serta sumber data lain yang diperoleh dari pihak lain yang berhubungan dengan penelitian ini.

Sampel yang digunakan dalam penelitian ini adalah teknik sampel non probability secara accidental sampling yaitu teknik pengambilan sampel yang tidak memberi peluang atau kesempatan yang sama bagi setiap unsur atau anggota populasi untuk dipilih menjadi sampel. Accidental sampling adalah teknik penentuan sampel berdasarkan kebetulan, yaitu siapa saja yang secara kebetulan bertemu dengan peneliti dapat digunakan sebagai sampel, bila dipandang orang yang kebetulan ditemui itu sesuai sebagai sumber data.

Sebanyak 107 orang yang ditemui secara kebetulan berkunjung ke Pantai ini pada saat pelaksanaan penelitian yang dijadikan sebagai sampel melalui metode kuesioner dengan jenis pertanyaan yang digunakan adalah pertanyaan tertutup dan terbuka serta semi terbuka yang telah disediakan alternatif jawaban.

Data yang telah dikumpulkan dari hasil penelitian terkait dengan tipologi (karakteristik, pola perjalanan) dan persepsi pengunjung dapat di analisis secara deskriptif kualitatif. Data-data yang di analisis berasal dari survei melalui kuesioner yang telah 
diberikan kepada pengunjung, meliputi data tentang profil pengunjung, pola perjalanan pengunjung, dan persepsi pengunjung tentang pantai Panrita Lopi ini.

\section{Hasil dan Diskusi}

Hasil survei lapangan pada tanggal 3 April 2021 yang dilakukan terhadap wisatawan atau pengunjung yang berkunjung ke pantai Panrita Lopi di Kecamatan Muara Badak Kabupaten Kutai Kartanegara 2021, Ada 107 pengunjung yang bersedia mengisi angket / kuesioner yang disebar pada areal pantai. Hasil karakteristik responden dapat dilihat sebagai berikut :

\section{A. PROFIL RESPONDEN}

\section{Jenis Kelamin}

Dari hasil grafik diatas, bahwa profil pengunjung wanita 50,5\% atau sebanyak 54 orang hampir seimbang dengan pengunjung laki-laki yakni sebanyak 53 orang atau 49,5 $\%$. Nampak jelas bahwa keberadaan pengunjung pada pesta pantai tersebut merata antara lelaki dan perempuan.

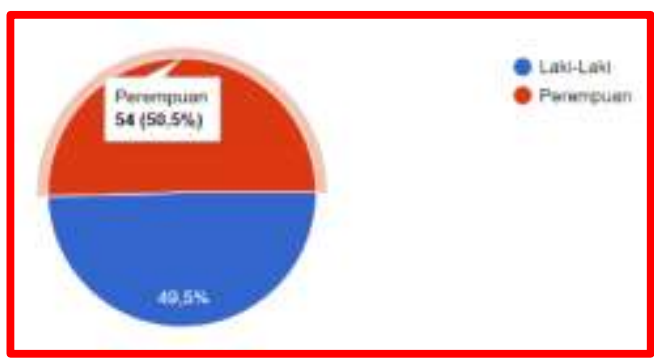

Gambar 1. Profil Jenis Kelamin

\section{Umur}

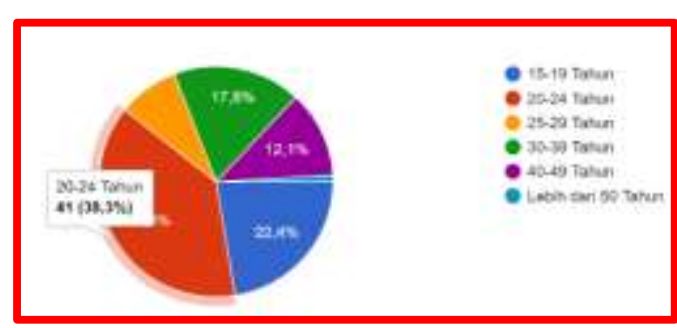

Gambar 2. Profil Umur

Dari hasil grafik dibawah nampak terlihat bahwa umur responden tertinggi adalah pada rentang usia 20 -24 thn sebanyak 38,3\% sedangkan urutan kedua terbanyak adalah 
di rentang usia 15 - 19 thn sebanyak 22,4\%. Nampak jelas terlihat bahwa kaum milenial usia muda sangat mendominasi kunjungan ke pantai, karena sifatnya yang lebih kearah alam dan petualangan.

\section{Pendidikan Terakhir}

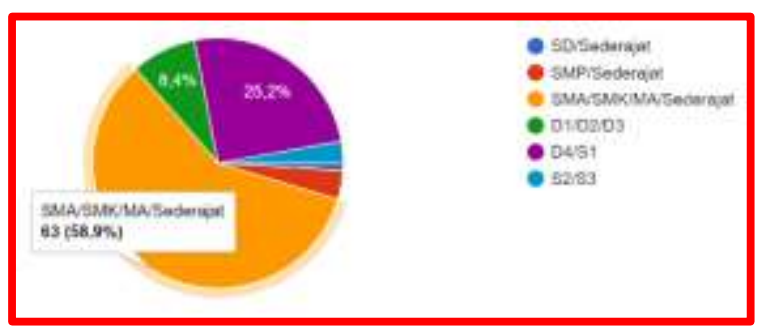

Gambar 3. Profil Pendidikan

Pada profil pendidikan bahwa kaum milenial sangat mendominasi, terlihat dari 107 responden kuesioner yang masuk yakni sebesar 58,9\% atau 63 orang telah berkunjung dan lulusan sarjana S1/D4 menempati urutan kedua yakni sebanyak 25,2\%. para remaja yang datang sangat haus akan hiburan dan kegiatan di akhir pekan.

\section{Daerah Asal}

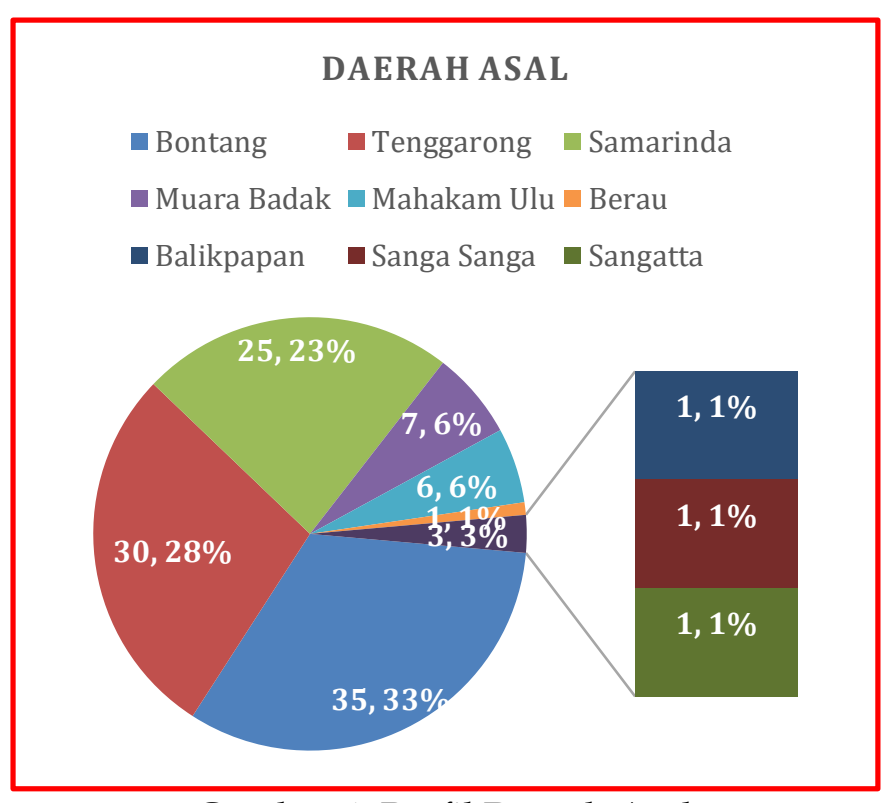

Gambar 4. Profil Daerah Asal 
Pada profil daerah asal, yang paling mendominasi adalah Pengunjung dari Bontang sebanyak 35\%, di ikuti pengunjung asal Tenggarong sebanyak 30\% dan pengunjung asal Samarinda sebanyak 23\%. Hal ini menunjukan bahwa Pengunjung pantai Panrita Lopi berasal dari wisatawan lokal, bahwa segmentasi pantai ini masih disekitaran lokasi daerah Muara Badak saja.

\section{Pekerjaan Saat ini}

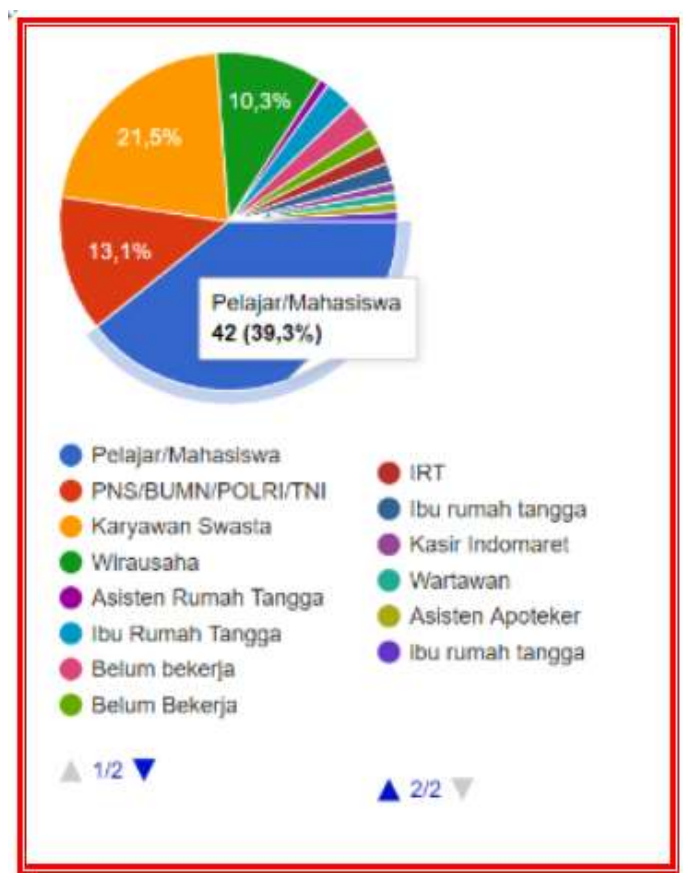

Gambar 5. Profil Pekerjaan

Pada tingkat pekerjaan responden atau wisatawan yang berkunjung ke pantai pada urutan pertama adalah pelajar/mahasiswa sebesar 42 orang atau sebesar 39,3\%. Sedangkan urutan kedua adalah karyawan swasta dengan prosentase sebesar $21,5 \%$ atau 23 orang maka nampak jelas bahwa profesi sebagai pelajar atau mahasiswa sangat mendominasi kunjungan. 


\section{Penghasilan Tiap Bulan}

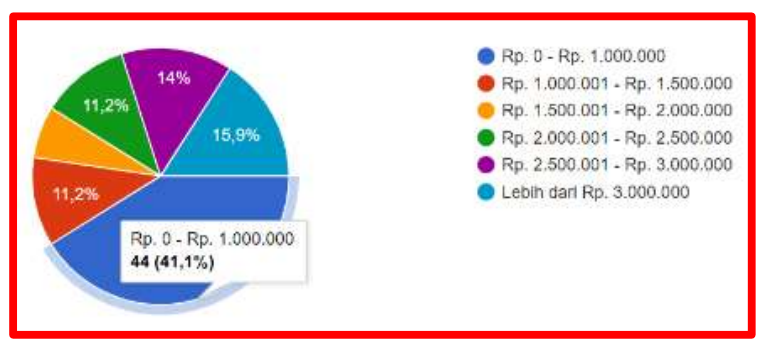

Gambar 6. Profil Penghasilan

Pada Grafik diatas terlihat bahwa profesi mahasiswa atau pelajar sangat mendominasi kunjungan ke pantai Panrita Lopi, ini pun terlihat dari segi pandapatan yang di isi oleh responden yakni sebesar $41,1 \%$ atau sebanyak 44 orang yang memiliki pendapatan paling rendah atau minimal sebesar Rp. 1 juta/bulan. Menurut analisa Penulis bahwa kunjungan pada event Pesta Pantai tidak terlalu berdampak besar kepada sektor ekonomi baik kepada para pedagang maupun pengusaha sektor pariwisata di sekitar pantai tersebut, karena mayoritas pengunjung adalah mereka yang belum mempunyai penghasilan tetap. Prioritas mereka adalah bukan untuk berbelanja tetapi hanya untuk berkunjung ke destinasi dengan angggaran minimum. Sedangkan pada urutan kedua ditempati oleh mereka yang berpenghasilan lebih dari Rp. 3 jt / bulan. penghasilan seseorang merupakan salah satu faktor penting untuk mendorong sesorang untuk memutuskan melakukan perjalanan wisata, dan orang yang memiliki penghasilan tetap setiap bulan cenderung lebih sering melakukan perjalanan wisata. Hal lain yang menarik adalah mereka yang berpenghasilan di atas Rp.3000.000 meskipun hanya (15,9\%) tidak berpengaruh terhadap biaya berwisata maka kelompok tersebut merupakan pasar potensial yang perlu menjadi sasaran strategi promosi ke depannya.

\section{B. POLA PERJALANAN}

Setelah Mengetahui profil responden yang datang berkunjung, maka pada bagian ini adalah ingin mengetahui Pola perjalanan Wisatawan yang berada di pantai. Berikut ini adalah gambaran karakteristik wisatawan yang ada, yakni : 


\section{Frekwensi mengunjungi tempat wisata}

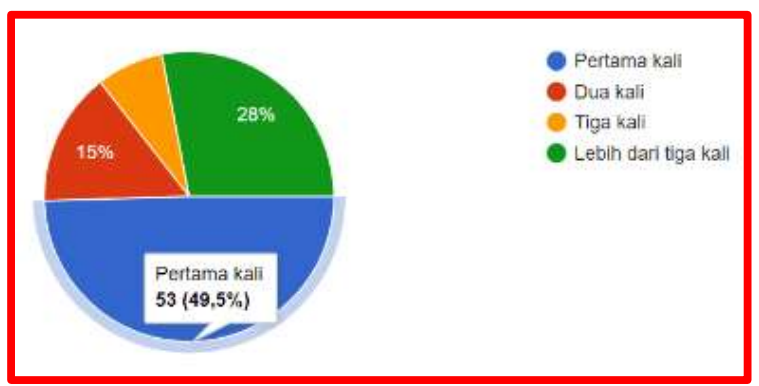

Gambar 7. Profil Jumlah Kunjungan

Berdasarkan grafik diatas pengunjung yang datang adalah merupakan kunjungan pertama kali ke Pantai Panrita Lopi menempati urutan paling atas, yakni sebesar 49,5\%. Hal ini berarti bahwa destinasi ini merupakan pengalaman baru bagi mereka. Pengunjung yang pertama kali mengunjungi pantai ini merupakan segmentasi pasar potensial yang diharapkan akan melakukan kunjungan kembali di masa-masa yang akan datang. Sedangkan urutan yang kedua adalah pengunjung yang repeatation (berulang kali) telah datang ke pantai ini atau telah lebih dari tiga kali. Artinya bagi pengunjung tersebut bahwa pantai ini sangat menarik dan tidak pernah bosan untuk selalu datang dan menikmati alam pantai, karena tercatat 28\% mereka telah datang lebih dari 3 kali

\section{Tujuan utama wisatawan berkunjung ke tempat wisata}

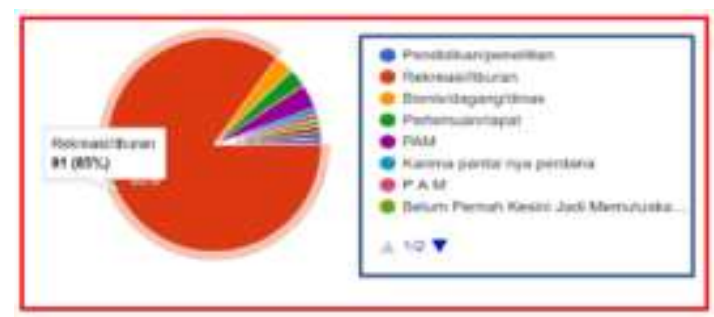

Gambar 8. Tujuan Berkunjung

Dari hasil grafik nampak terlihat jelas bahwa yang menjadi tujuan utama berkunjung adalah untuk berekreasi atau liburan menikmati alam pantai Panrita Lopi. Ini terlihat dari hasil kuesioner yang dibagikan ada sebesar $85 \%$ pengunjung yang memilihnya. Berdasarkan karakteristik tujuan utama berwisata tersebut menunjukkan bahwa kegiatan Event Pesta Pantai tersebut merupakan daya tarik bagi wisatawan, karena suasana panorama alam pantai yang masih sejuk menjadi daya Tarik bagi wisatawan. 


\section{Alasan memilih tempat wisata ini}

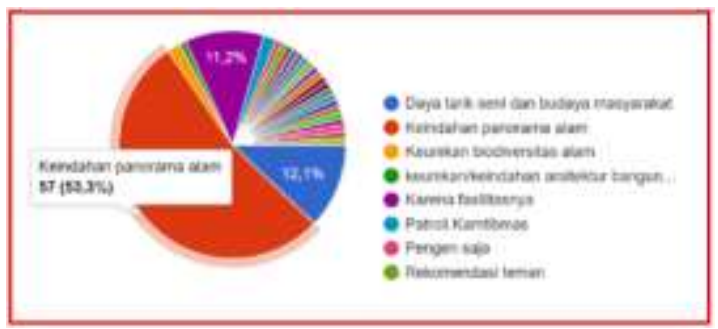

Gambar 9. Alasan Memilih Tempat

Setelah mengetahui tujuan utama dari berkunjung ke destinasi ini, maka selanjutnya adalah alasan untuk berkunjung. Seperti tampak pada grafik diatas bahwa alasan utama pengunjung adalah karena keindahan panorama alam yang paling tinggi yakni sebesar $53,3 \%$, sedangkan urutan kedua adalah karena alasan daya tarik seni dan budaya masyarakat yakni sebesar 12,1\%. Berdasarkan hasil tersebut maka dapat disimpulkan bahwa panorama alam Pantai Panrita Lopi sangat bagus untuk dinikmati oleh wisatawan.

\section{Sumber Informasi mengenai tempat wisata ini}

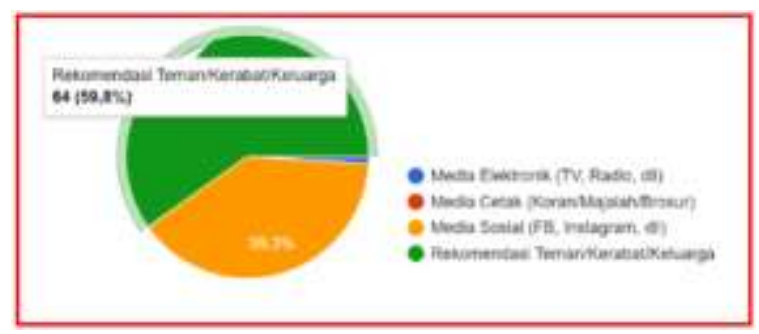

Gambar 10. Sumber Informasi

Berdasarkan informasi diatas bahwa sumber informasi yang didapatkan pengunjung mengenai pantai Panrita Lopi ini adalah bersumber pada rekomendasi dari teman/kerabat ataupun keluarga, ini terbukti dengan besaran 59,8\% di urutan teratas. Sedangkan informasi yang bersumber dari media sosial berada di urutan kedua yakni sebesar 39,3\%. Data in menunjukan bahwa promosi lewat mulut ke mulut memiliki pengaruh yang signifikan untuk mempromosikan suatu destinasi wisata. mereka lebih sering melakukan perjalanan wisata, oleh karena itu mereka akan menyampaikan kepada teman dan keluarga mereka tentang objek wisata yang pernah dikunjungi. 


\section{Bersama siapa}

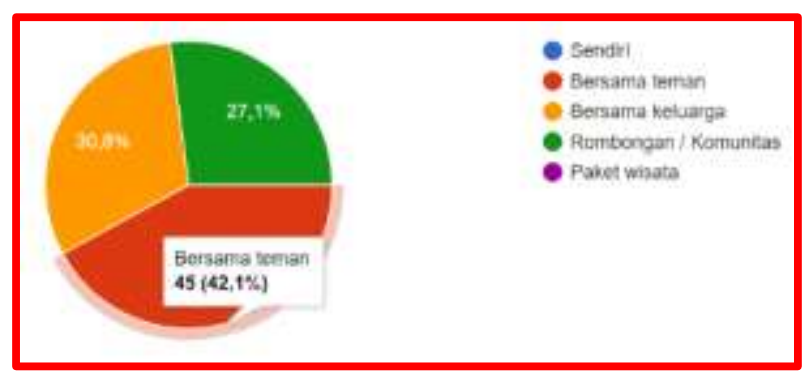

Gambar 11. Teman Berwisata

Kemudian partner atau mitrayang menjadi teman untuk berkunjung ke destinasi ini yang paling banyak adalah bersama teman atau rekan dengan jumlah tertinggi sebesar $42,1 \%$ sedangkan bersama keluarga menempati urutan kedua dengan jumlah sebesar 30,8\%. Hal ini menunjukan bahwa bersama teman berkunjung ke wisata pantai sangat menarik untuk dinikmati selain bersama keluarga. karakteristik wisatawan domestik dan wisatawan lokal cenderung lebih suka melakukan perjalanan wisata secara berkelompok.

\section{Waktu Untuk Berwisata}

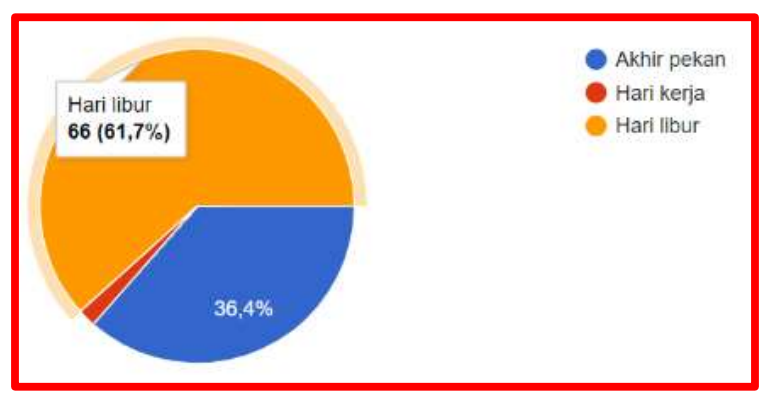

Gambar 12. Waktu Untuk Berwisata

Berdasarkan data diatas bahwa Karakteristik Responden atau Wisatawan terkait waktu berkunjung ke tempat wisata di dominasi pada saat hari libur yakni sebesar 61,7\% dan kunjungan pada akhir pekan sebesar 36,4\%. Hal ini menunjukkan bahwa waktu kunjungan wisatawan sangat terkait dengan karakteristik pekerjaan wisatawan karena sebagian besar kunjungan dilakukan pada hari libur dan akhir pekan yang merupakan waktu libur bagi pekerja/karyawan terutama PNS/BUMN/TNI/ POLRI dan karyawan Swasta. 


\section{Lama Waktu Berwisata}

Rata- rata waktu yang dihabiskan untuk berwisata adalah lebih dari 3 jam dengan prosentase sebesar 72,9\% dan di urutan kedua rata-rata 2 - 3 jam dengan jumlah 27,1\% ini menandakan bahwa untuk menikmati panorama alam di pantai Panrita Lopi tidak bisa sebentar, melainkan butuh waktu yang panjang.

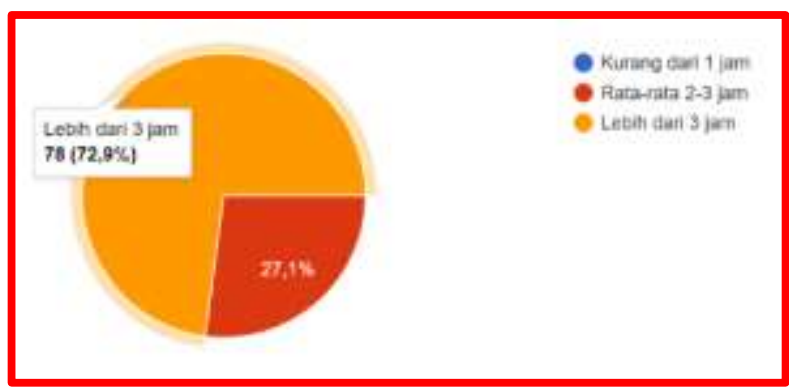

Gambar 13. Lama Waktu Berwisata

Dari data tersebut hendaknya pihak pengelola pantai lebih banyak atraksi dan variasi yang disajikan kepada pengunjung agar bisa lebih banyak menghabisakan waktu dan juga uang di tempat wisata ini.

\section{Biaya Yang Dikeluarkan}

Jumlah biaya yang dikeluarkan saat berada di pantai ini itu antara Rp. 50rb - Rp. 100rb dengan prosentase tertinggi sebesar 39,3\% dan urutan kedua pengunjung menghabiskan biaya sebesar Rp 101rb - 200rb dengan jumlah prosentase 25,2 \%.

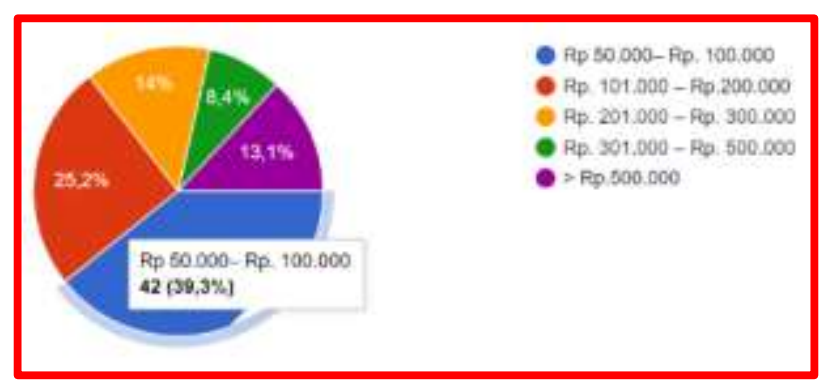

Gambar 14. Biaya yang dikeluarkan Selama Berwisata

Hal ini menunjukan bahwa perputaran uang yang beredar di destinasi ini tidak banyak, atau tidak terlalu banyak yang bisa dibeli, sehingga pengunjung sangat terbatas 
membelanjakan uangnya. Sebaiknya pihak pengelola menggandeng pengusaha lokal dengan skala mikro untuk bekerjasama dalam membuka lapak usaha dagang di daerah pantai ini

\section{PERSEPSI WISATAWAN}

\section{Kondisi Secara Umum}

Berdasarkan tingkat kepuasan wisatawan selama berada di destinasi wisata, berikut persentase persepsi wisatawan yang berkunjung di pantai Panrita Lopi, Kecamatan Muara Badak. pada tahun 2021.

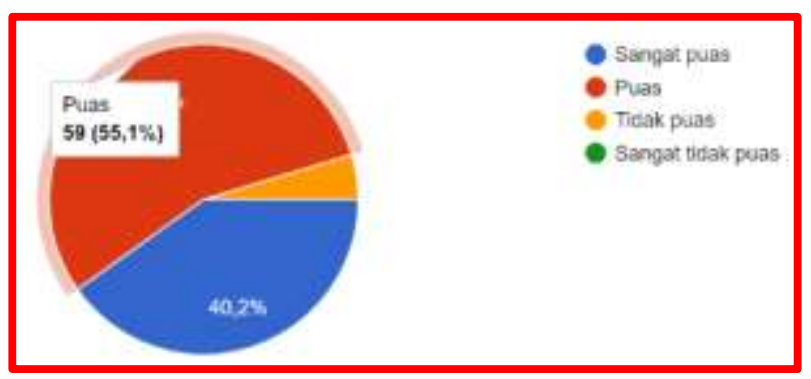

Gambar 15. Kondisi Destinasi Wisata

Sebanyak 59 pengunjung atau 55,1\% menyatakan Puas dengan kondisi pantai Panrita Lopi.

\section{Keragaman Atraksi Wisata}

Berdasarkan tingkat kepuasan wisatawan terhadap keragaman atraksi wisata, berikut ini persentase persepsi wisatawan yang berkunjung di pantai Panrita Lopi, Kecamatan Muara Badak. pada tahun 2021.

Sebanyak 70 pengunjung atau 65,4\% menyatakan Puas dengan keragaman atraksi wisata di pantai Panrita Lopi. 


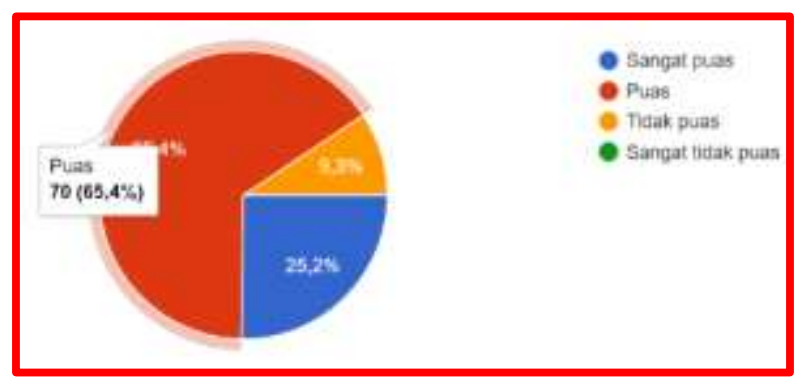

Gambar 16. Keragaman Atraksi Wisata

\section{Tempat Parkir}

Berdasarkan tingkat kepuasan wisatawan terhadap tempat parkir, berikut ini persentase persepsi wisatawan yang berkunjung di pantai Panrita Lopi, Kecamatan Muara Badak. pada tahun 2021.

Sebanyak 72 pengunjung atau 67,3\% menyatakan Puas dengan tempat parkir di pantai Panrita Lopi.

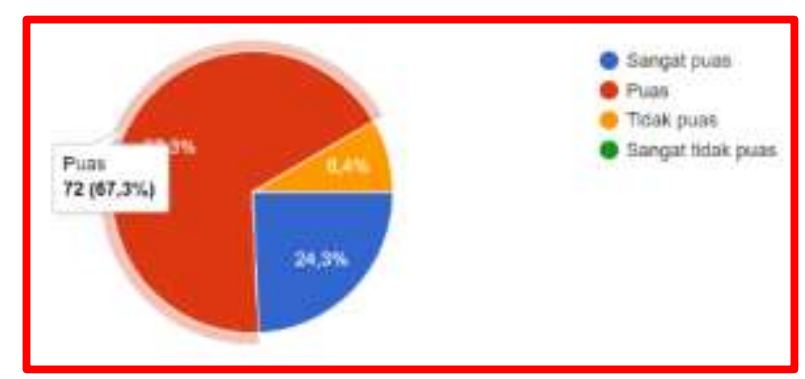

Gambar 17. Tempat Parkir

\section{Toilet}

Berdasarkan tingkat kepuasan wisatawan terhadap toilet, berikut ini persentase persepsi wisatawan yang berkunjung di pantai Panrita Lopi, Kecamatan Muara Badak. pada tahun 2021.

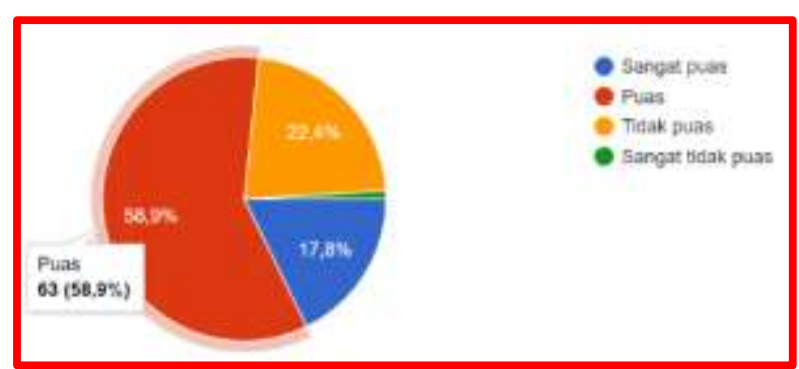

Gambar 18. Toilet 
Sebanyak 63 pengunjung atau 58,9\% menyatakan Puas dengan toilet di pantai Panrita Lopi.

\section{Pelayanan Informasi Oleh Petugas}

Berdasarkan tingkat kepuasan wisatawan terhadap pelayanan informasi oleh petugas, berikut ini persentase persepsi wisatawan yang berkunjung di pantai Panrita Lopi, Kecamatan Muara Badak. pada tahun 2021.

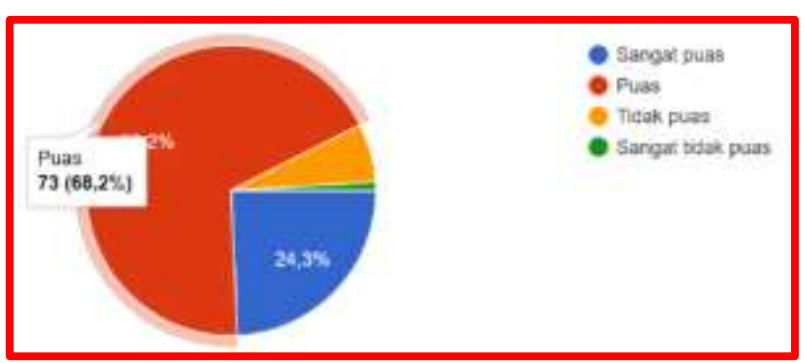

Gambar 19. Pelayanan Informasi

Sebanyak 73 pengunjung atau $68,2 \%$ menyatakan Puas dengan pelayanan informasi oleh petugas di pantai Panrita Lopi.

\section{Kualitas Cinderamata}

Berdasarkan tingkat kepuasan wisatawan terhadap kualitas cinderamata, berikut ini persentase persepsi wisatawan yang berkunjung di pantai Panrita Lopi, Kecamatan Muara Badak. pada tahun 2021.

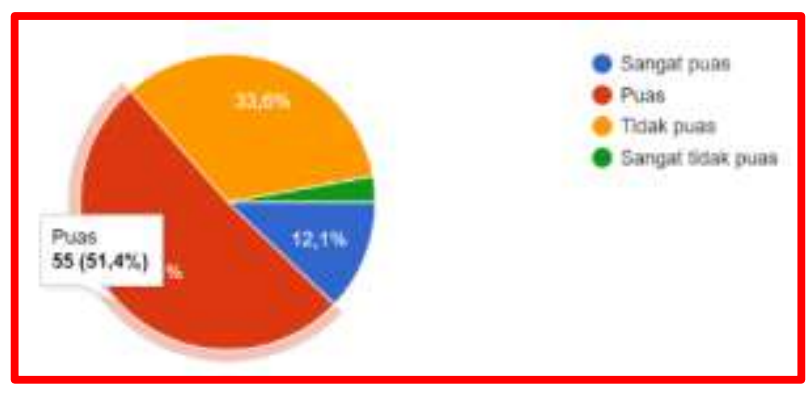

Gambar 20. Pelayanan Informasi 
Sebanyak 55 pengunjung atau 51,4\% menyatakan Puas dengan kualitas cinderamata di pantai Panrita Lopi.

\section{Harga Kuliner}

Berdasarkan tingkat kepuasan wisatawan terhadap harga kuliner, berikut ini persentase persepsi wisatawan yang berkunjung di pantai Panrita Lopi, Kecamatan Muara Badak. pada tahun 2021.

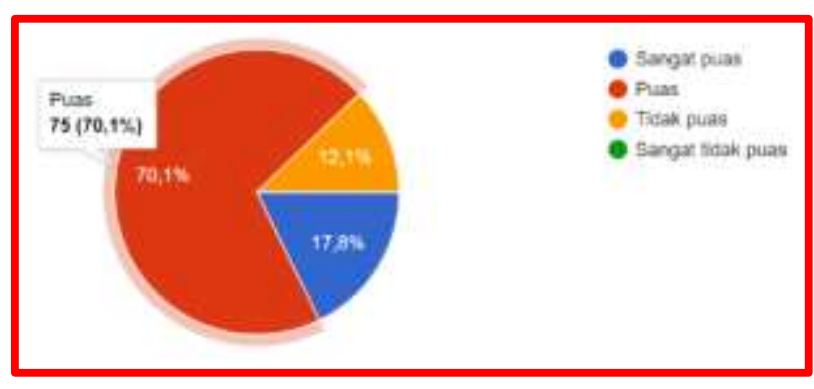

Gambar 21. Harga Kuliner

Sebanyak 75 pengunjung atau 70,1\% menyatakan Puas dengan harga kuliner di pantai Panrita Lopi.

\section{Kondisi Jalan}

Berdasarkan tingkat kepuasan wisatawan terhadap kondisi jalan, berikut ini persentase persepsi wisatawan yang berkunjung di pantai Panrita Lopi, Kecamatan Muara Badak. pada tahun 2021.

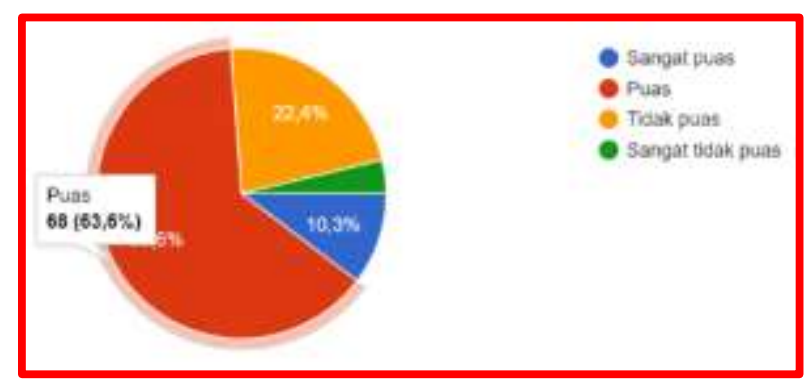

Gambar 22. Kondisi Jalan

Sebanyak 68 pengunjung atau 63,6\% menyatakan Puas dengan kondisi jalan di pantai Panrita Lopi. 


\section{Kebersihan Lingkungan}

Berdasarkan tingkat kepuasan wisatawan terhadap kebersihan lingkungan, berikut ini persentase persepsi wisatawan yang berkunjung di pantai Panrita Lopi, Kecamatan Muara Badak. pada tahun 2021.

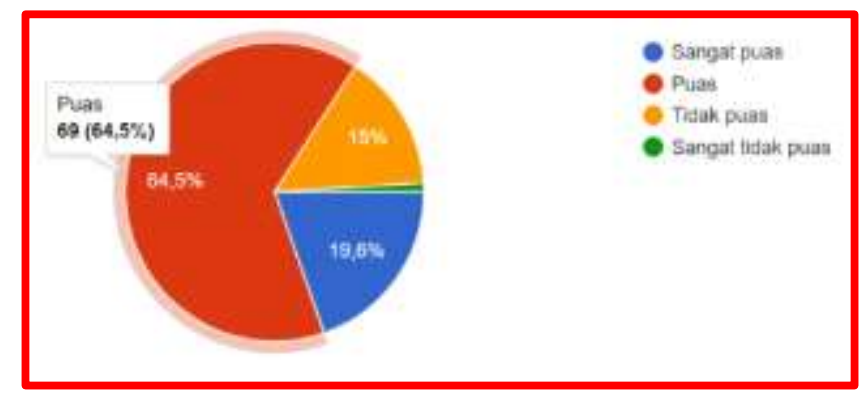

Gambar 23. Kebersihan Lingkungan

Sebanyak 69 pengunjung atau 64,5\% menyatakan Puas dengan kebersihan lingkungan di pantai Panrita Lopi.

\section{Kesimpulan}

Berdasarkan hasil analisis terhadap berbagai karakteristik pengunjung, dan persepsi tingkat kepuasan tentang destinasi pantai Panrita Lopi, di Kec. Muara Badak, Kab. Kutai Kartanegara pada tahun 2021 dapat disimpulkan bahwa Profil Responden terdiri atas ; Jenis kelamin adalah perempuan sebesar $50,4 \%$, usia didominasi oleh $20-24^{\text {th }}$ sebesar $38,3 \%$, pendidikan terakhir adalah SMA/Sederajat sebesar 58,9\%, pekerjaan adalah dari mahasiswa sebanyak 39,3\% dan penghasilan tiap bulan dibawah Rp.1.000.000.- sebesar 41,1\%

Frekwensi mengunjungi wisata ini yang memilih pertama kali sebesar 49,5\%, tujuan utama berkunjung adalah untuk rekreasi liburan sebesar $85 \%$, alasan memilih tempat wisata sebesar 53,3\% karena keindahan panorama alam, sumber informasi mengenai tempat wisata ini berasal dari rekomendasi teman 59,8\%, berwisata bersama teman sebesar $42,1 \%$, waktu kunjungan pada hari libur sebesar 61,7\% dan lama kunjungan waktu kunjungan lebih dari 3 jam sebesar 72,9\% serta biaya yang dikeluarkan selama melakukan kunjungan wisata sebesar Rp.50100rb sebesar 39,3\%. 
Edutourism Journal of Tourism Research $\quad$ p-ISSN: 2686-4746 e-ISSN: 2721-1371

Untuk Persepsi Wisatawan terhadap kondisi Secara umum destinasi pantai, keragaman atraksi wisata, tempat parkir, toilet, pelayanan informasi oleh petugas, kualitas cinderamata, harga kuliner, kondisi Jalan serta kebersihan lingkungan semua responden menyatakan puas. 


\section{Author's declaration}

\section{Authors' contributions and responsibilities}

Write the contribution of each author here or mark the following column.

$\sqrt{ }$ The authors made substantial contributions to the conception and design of the study.

$\sqrt{ }$ The authors took responsibility for data analysis, interpretation, and discussion of results.

$\sqrt{ }$ The authors read and approved the final manuscript.

\section{Availability of data and materials}

$\sqrt{ }$ All data are available from the authors.

Competing interests

$\sqrt{ }$ The authors declare no competing interest. 
Edutourism Journal of Tourism Research $\quad$ p-ISSN: 2686-4746 e-ISSN: 2721-1371

\section{References}

[1] Cooper Chris et al, 1999. Tourism Principles and Practice. Harlow, England : Financial Times Prentice Hall, 1999.

[2] Cohen dalam Pitana 2010, diambil https://herindiyah.wordpress.com/2019/09/09/motivasi-perjalanan-wisata/ (diakses 5 Okt 2021)

[3] Ginting, M.S.B., Negara, I.M.K., Sudiarta, I.N. 2015. Analisis Segmentasi Pasar Wisatawan Mancanegara yang Berkunjung ke Bali dari Aspek Sosio-Ekonomi Demografi, Psikografi, dan Perilaku. Jurnal IPTA, Vol.3 No. 2, 98 - 101

[4] Keliwar Said \& Nurcahyo Anton, 2015. Persepsi Pengunjung terhadap Objek Wisata Desa Budaya Pampang di Samarinda, Jurnal Manajemen Resort dan Leisure Vol.12, Oktober 2015. UPI Bandung.

[5] Kotler Philip, 2009. Manajemen Pemasaran Edisi 12 Edisi Bahasa Indonesia. PT INDEKS.

[6] Kasali, Rhenald 2000. "Membidik Pasar Indonesia" Segmenting, Targeting dan Positioning, Gramedia, Jakarta

[7] Peraturan Pemerintah (PP) No. 50 Tahun 2011 tentang Rencana Induk Pembangunan Kepariwisataan Nasional Tahun 20102025

[8] Tjiptono Fandy, 1997. Strategi Pemasaran Edisi II. Yogyakarta. Penerbit ANDI Yogyakarta.

[9] Wiranatha A.A.P. Agung Suryawan et. Al, 2018. Analisa Pasar Wisatawan Mancanegara di Kota Denpasar. Dinas Pariwisata Kota Denpasar Bekerjasama dengan Pusat Penelitian Kebudayaan dan Kepariwisataan Udayana.

[10] Yoety, Oka A. 2002. Perencanaan Strategis Pemasaran Daerah Tujuan Wisata. Jakarta: Pradnya Paramita 